\title{
Female of Childbearing Potential
}

National Cancer Institute

\section{Source}

National Cancer Institute. Female of Childbearing Potential. NCI Thesaurus. Code C161316.

A female study subject or patient who has the potential to become pregnant. 